\title{
Understanding Economic Growth China and India
}

A Comparative Study of Selected Issues 
This page intentionally left blank 


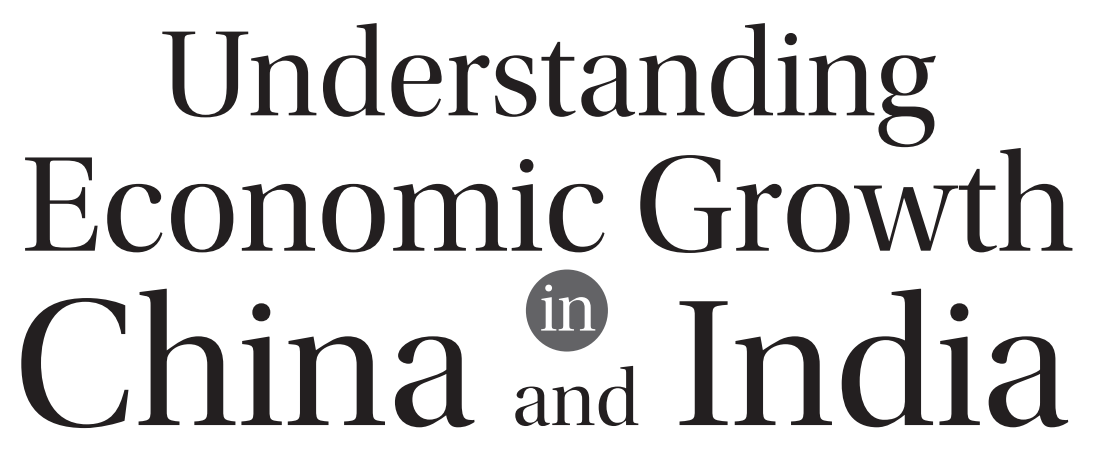

A Comparative Study of Selected Issues

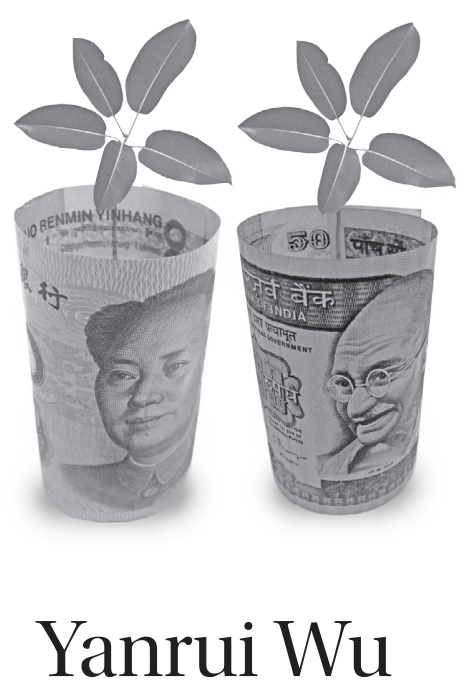

University of Western Australia, Australia 
Published by

World Scientific Publishing Co. Pte. Ltd.

5 Toh Tuck Link, Singapore 596224

USA office: 27 Warren Street, Suite 401-402, Hackensack, NJ 07601

UK office: 57 Shelton Street, Covent Garden, London WC2H 9HE

\section{British Library Cataloguing-in-Publication Data}

A catalogue record for this book is available from the British Library.

\section{UNDERSTANDING ECONOMIC GROWTH IN CHINA AND INDIA A Comparative Study of Selected Issues}

Copyright () 2012 by World Scientific Publishing Co. Pte. Ltd.

All rights reserved. This book, or parts thereof, may not be reproduced in any form or by any means, electronic or mechanical, including photocopying, recording or any information storage and retrieval system now known or to be invented, without written permission from the Publisher.

For photocopying of material in this volume, please pay a copying fee through the Copyright Clearance Center, Inc., 222 Rosewood Drive, Danvers, MA 01923, USA. In this case permission to photocopy is not required from the publisher.

ISBN-13 978-981-4287-78-4

ISBN-10 981-4287-78-4

In-house Editor: Wanda Tan

Typeset by Stallion Press

Email: enquiries@stallionpress.com

Printed in Singapore. 


\section{Preface}

The economies of China and India, the world's two most populous nations, have attracted a lot of attention in recent years. Even a new term, "Chindia", was created to refer to the two countries together in general. There are many comparative studies of the two Asian giants. This volume focuses exclusively on economic growth and several critical issues associated with growth in the two economies. It combines quantitative examination with qualitative analysis. It not only provides valuable insights into those growth-related issues, but also raises many questions which are to be explored in the future. The volume should be of interest to postgraduate students, researchers and business analysts. In particular, the materials in the appendices to some chapters are important resources for other researchers who are interested in the economies of China and India.

My work on this book spans several years. It began with my visit to the East Asian Institute (EAI), at the National University of Singapore (NUS), during my sabbatical leave in 2005; subsequently, I visited EAI several times. I benefited a lot from the library resources at EAI and participation in many seminars and conferences there. Work on some chapters also benefited from the financial support of a University of Western Australia (UWA) Research Grant as well as an Australian Research Council (ARC) Discovery Project Grant (DP1092913). I would also like to thank seminar participants at EAI (NUS), the economics group (UWA), School of Management (University of Bradford), and China 
Research Centre (University of Technology, Sydney) for helpful comments and suggestions. I also acknowledge James Tsun Se Cheong, Rebecca Doran-Wu, Hetish Gupta and Nic Yew Sin for their excellent research assistance.

$$
\begin{array}{r}
\text { Yanrui Wu } \\
\text { University of Western Australia } \\
\text { Perth, Australia }
\end{array}
$$




\section{Contents}

Preface $\quad$ v

List of Tables $\quad$ ix

List of Figures $\quad$ xi

Chapter 1 Introduction 1

Chapter 2 Growth Since the 1980s 7

Chapter 3 Regional Growth and Convergence 33

Chapter 4 Role of the Service Sector 67

Chapter 5 Changing Bilateral Trade 85

Chapter 6 Energy Consumption and Carbon Emission $\quad 99$

Chapter $7 \quad$ Pollution Control and Economic Growth 121

$\begin{array}{lll}\text { Chapter } 8 \text { Conclusion } & 137\end{array}$

Bibliography 143

$\begin{array}{ll}\text { Index } & 159\end{array}$ 
This page intentionally left blank 


\section{List of Tables}

1.1 Summary Information of the Core Chapters 5

2.1 Chronicle of Selected Events in China and India 9

2.2 Growth Rates and Per Capita GDP in Selected 11 Economies

2.3 Sources of Economic Growth in China and India 17

2.4 Sector Shares (\%) of GDP and Employment 19

2.5 Sources of India's Economic Growth: Alternative 19 Results

2.6 Summary of Findings in the Literature 20

2.7 Contributions to Growth at the Sector Level 22

A2.1 Capital Stock Series for China and India 27

A2.2 GDP and Employment Shares (\%) by Sector 29 in China and India

3.1 Ranking of Chinese and Indian Regional 37 Economies

3.2 Estimation Results of Beta-Convergence: $\beta$ Values $\quad 40$

3.3 Estimation Results $\quad 45$

3.4 Sensitivity Analysis $\quad 47$

A3.1 Level of Urbanization in Chinese and Indian 48 Regions

A3.2 Gross Regional Product (GRP) Per Capita in 50

China, 1980-2009

A3.3 Gross Regional Product (GRP) Per Capita in 56

India, 1980/81-2009/10

4.1 Composition of Service Sector GDP (2003, \%) 71

4.2 Estimation Results 80 
4.3 Service Sector Shares in Selected Economies 82

5.1 Top Trading Partners of China and India 89

5.2 China-India Trade Shares by Commodity 91 in Selected Years

5.3 Intensity of Trade Between China and India 92

5.4 Intra-Industry Trade Indices $\quad 94$

5.5 Comparative Advantage Indices 95

5.6 Structure of the Chinese and Indian Economies 97 (\% of GDP)

6.1 Estimation Results 106

6.2 Summary Statistics of Selected Economies 108

7.1 Ambient Air Quality Status 123

(annual average, $\mu \mathrm{g} / \mathrm{m}^{3}$ )

7.2 $\mathrm{CO}_{2}$ Emission and Intensity, $2006 \quad 129$

7.3 Selected Laws and Regulations Promulgated 134 in China and India 


\section{List of Figures}

1.1 GDP Shares (\%) of Selected Economies over 2 the World Total, 1500-2030

2.1 Economic Growth in China and India, 1953-2010 10

2.2 Rates of Economic Growth and Capital 16 Accumulation, 1980-2009

2.3 Labor Productivity Indices by Sector 21

2.4 Income Per Capita Indices of Chinese and 23 Indian States

2.5 Service Sector Shares over GDP vs. GDP Per 24 Capita, 2003

2.6 Growth Rates vs. Gross Capital Formation over GDP

3.1 Regional Ranking and Growth Rates 34

3.2 Sigma-Convergence of Regional Income 38

4.1 GDP Shares by Sector in China and India, 68 1983-2009

4.2 Service Sector Share over Total GDP, 1978-2009 73

4.3 Employment Shares of the Service Sectors, 73 1983-2009

4.4 GDP Per Capita and Service Sector GDP Shares $\quad 75$ in Chinese Regions, 2007

4.5 GDP Per Capita and Service Sector GDP Shares $\quad 75$ in Indian Regions, 2007

4.6 Economic Structure and Level of Development 76

4.7 Service Sector GDP Shares and GDP Per Capita $\quad 77$ Across Countries, 2007 
5.1 Total Value of Trade in China and India, 86 1992-2009

5.2 Openness in China and India, 1992-2009 87

5.3 Indian Exports to and Imports from China, 88 1986-2007

6.1 Energy Consumption and GDP in Selected Economies, 2006

6.2 $\mathrm{CO}_{2}$ Emission and GDP in Selected Economies, 2006

6.3 $\mathrm{CO}_{2}$ Emission and Energy Consumption in Selected Economies, 2006

6.4 Energy Intensity, Carbon Emission Intensity and Income in Group-26

6.5 Energy Intensity and Carbon Emission Intensity in China and India

6.6 Energy Intensity, Carbon Emission Intensity and Income in Group-5

A6.1 Energy Consumption and Income (PPP-based) in Selected Economies, 2006

A6.2 Energy Consumption, $\mathrm{CO}_{2}$ Emission and GDP in Selected Economies, 2006

A6.3 $\quad \mathrm{CO}_{2}$ Emission and Income (PPP-based) in Selected Economies, 2006

A6.4 Energy Intensity, Carbon Emission Intensity and Income, 2006

A6.5 Energy Intensity, Carbon Emission Intensity and PPP-Based Income, 2006

A6.6 Energy Consumption, Carbon Emission and Income in Group-26

7.1 China: Total Waste Discharged, 1998-2010

7.2 The Number of Motor Vehicles in China and India, 1993-2009

7.3 Energy Consumption and GDP in Selected Economies, 2006

8.1 Growth and Income Per Capita in Four Asian Economies 